Article

\title{
Creating the Habit of Recycling in Early Childhood: A Sustainable Practice in Spain
}

\author{
Pilar Buil ${ }^{1, *\left(\mathbb{O}, \text { Olga Roger-Loppacher }^{1} \text { and Mireia Tintoré }\right.}{ }^{2}$ (i) \\ 1 School of Communication, Universitat Internacional de Catalunya, Immaculada 22, 08127 Barcelona, Spain; \\ oroger@uic.es \\ 2 Faculty of Education, Universitat Internacional de Catalunya, 08127 Barcelona, Spain; mtintore@uic.es \\ * Correspondence: pbuil@uic.es; Tel.: +34-93-2541800
}

Received: 19 October 2019; Accepted: 8 November 2019; Published: 14 November 2019

\begin{abstract}
Early childhood education on sustainability has been an issue of high relevance in the last decade. In Spain, many different efforts have been made to increase children's knowledge, skills, and awareness related to sustainability issues. However, uncertainty about the effectiveness of education on sustainable development exists. This research reports on an exploratory study organized by the association that promotes aluminum packaging recycling in Spain (Arpal). Seven teachers were trained on sustainability in general and on aluminum packaging recycling in particular. These teachers defined and implemented a teaching unit with active learning activities that involved three preschools. Fifty-four children under 6 years of age, mainly 2 and 3 years old, along with their parents, participated in the teaching unit. Qualitative and quantitative methods (questionnaires, in-depth interviews, and focus groups) were carried out to assess the impact. The results proved that different partners, such as children, parents, teachers, managers, and associations, can work together with the common goal of improving education on sustainable development in early childhood, and all of them benefit from this collaboration. Moreover, this study confirmed that education on sustainability should be embedded in the daily routine of preschools. Furthermore, after the exploratory study, the teaching unit was implemented in 29 Andalusian preschools.
\end{abstract}

Keywords: environmental children's education; early childhood; sustainable development

\section{Introduction}

Sustainable development is considered a relevant and critical issue in contemporary societies [1-5]. In the field of education, special attention has been paid to sustainability [4,6-8]. Knowing that sustainable development is often considered to be an integrated concept with three pillars (environmental, economic, and social $[9,10]$ ), this paper focuses on environmental issues. Moreover, the research concentrated on education for sustainable development in early childhood [11,12], and particularly on the habit of recycling (see Figure 1), as this is a practice necessary to avoid the depletion of natural resources. Furthermore, different studies have shown that children can engage with ideas related to the environment when the issues connect mightily with localized experiences, such as recycling.

Education about the environment highlights the individual's active participation and contribution in coping with environmental problems and making sustainable choices [13]. However, despite the efforts made to increase people's awareness, skills, and sensitivity toward caring for the environment, there are doubts about the effectiveness of some of these programs and whether they contribute to sustainability [14]. It has been found that knowledge does not easily lead to a change in behavior $[15,16]$. On the other hand, it seems that these programs have overlooked children as relevant stakeholders [17] and that environmental education researchers did not direct their interest to very young children 
until 2007 [18,19]. Besides, according to Iliopoulou [20], research studying very young children's understanding of waste management has shown that most of them regard waste disposal and recycling as others' responsibility, and only a minority in that study talked about action.

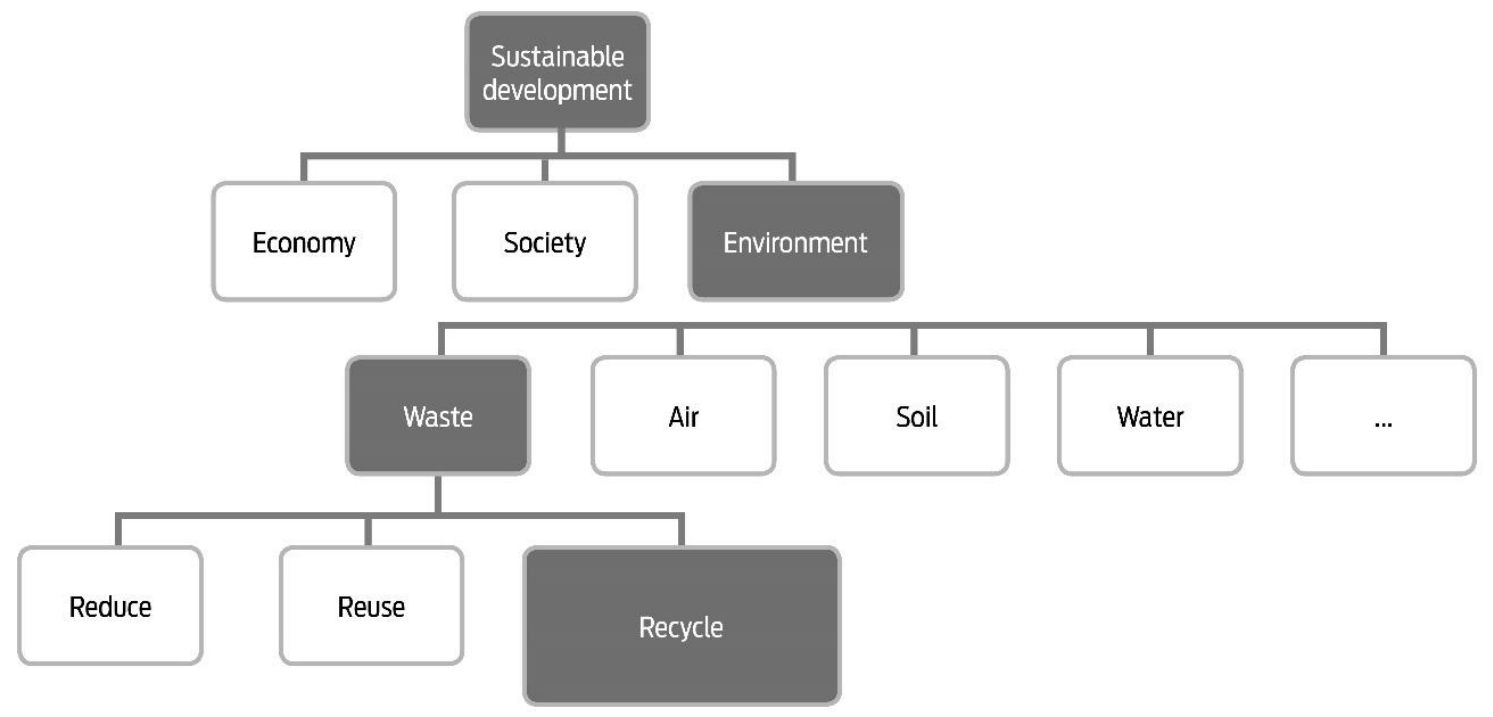

Figure 1. Position of "recycling" within the framework of sustainable development. Source: authors.

For all of these reasons, this study aimed to define and implement a teaching unit that develops the habit of recycling in early childhood by focusing on a concrete sustainable practice: aluminum packaging recycling. Aluminum was chosen for several reasons. Firstly, it is a material that children are familiar with because they see and use it almost every day (foil wrapping for sandwiches, yogurt lids, pouches, etc.). Secondly, recycling aluminum creates significant environmental advantages, such as reducing consumption of the mineral bauxite and reducing energy consumption by $95 \%$ when manufacturing new products. Thirdly, aluminum can be recycled indefinitely without losing its attributes. The amount of aluminum packaging that is recycled should be increased in Spain in order to achieve the rates established by European regulations: $50 \%$ before 2025 and $60 \%$ before 2030 (https://eur-lex.europa.eu/eli/dir/2018/852/oj) [21].

Thus, this study had the following research objectives:

1. Determine the levels of knowledge, awareness, and behavior that teachers, children, and parents have about sustainability in general and the recycling of aluminum packaging in particular;

2. Train teachers to design a teaching unit that educates children about sustainability in general and the recycling of aluminum packaging in particular; and

3. Assess the effectiveness of the aluminum packaging recycling program for teachers, children, parents, and preschools.

We approached our research questions according to this sequence. First, our purpose was to assess managers' willingness to participate in educational programs to promote sustainability to children. Second, through the implementation of workshops, we trained teachers about sustainability in general and the recycling of aluminum packaging in particular. According to Varela-Losada, teachers play a key role, especially given the transition toward schools and communities committed to the environment and people [22]. Third, seven teachers developed and implemented a teaching unit to involve children and families in recycling activities.

This paper is organized as follows: first, we present the framing used to conceptualize early education on sustainability. Then, we describe the methodology. The results are presented afterwards. Finally, we engage in a more in-depth discussion, providing some concluding remarks and implications for future research. 


\section{Education for Sustainable Development in Early Childhood}

The application of education for sustainability practices in early childhood has progressed slowly [23]. While it is true that sustainable development deals with abstract and complex relationships that are especially difficult for children [24], many authors have stressed the importance of environmental education, and some say that education in environmental sustainability should start in childhood [18,25-29]. In addition, early childhood education could play an essential role in sustainable practice, as it is considered to be a period of time when children's main attitudes and values are established for the first time [27,30-33]. According to Davis [12], the experiences provided for young children are influential to their present and future beliefs, values, well-being, and individual and social development. Furthermore, children represent the interface between current and future generations [17].

In terms of early childhood sustainability education, attention to experiential learning is central and lies at the heart of early childhood education [33]. Learning through games and active exploration of the environment has been considered a characteristic of early learning [34]. Besides, cooperation between families and preschools appears to be a critical element when trying to obtain long-term benefits [35]. MacDonald [36] has highlighted that early childhood sustainability education should be promoted through active, collaborative, project-based methods rooted in self, family, school, and community. Chauhan, Rama Das, Haigh, and Rita [37] pointed out that pro-sustainability orientation includes changing habits and making sustainable choices as a matter of daily routine.

Additionally, there is room in the preschool setting to build connections with and participate in the community around them and to take advantage of physical and social resources in the district. This view is incorporated within place-based education, in which children learn to understand, value, and care for the heritage, culture, and landscape of the place where they live. As Luff points out [33] (p. 453) (after several studies), "Children who have opportunities to explore, connect with, and appreciate the places where they live develop a sense of care for self, others, and the environment. This can lead to work on local social and environmental projects and growing appreciation of wider national and global issues." In summary, the literature recognizes the necessity of organizing experiences in early childhood environmental education that allow for maximum interaction and communication between teachers, children, and their families [38].

From the point of view of teaching, following Loubser et al., "The implementation of environmental education programs and activities conducted by teachers for their own students would seem advantageous in ensuring both continuity and the positive impacts of environmental education programs on school students, as teachers are familiar with the curricula and the time availability of students" [14] (p. 1165). Furthermore, it was found that to implement environmental education, it is necessary not only that teachers know how to educate young children, but also that they know general concepts of sustainability [38]. Therefore, governments and international organizations must provide the means for this to happen [35]. Moreover, according to Hopkins and McKeown [39], it is necessary that nonformal organizations and the private sector support formal education to ensure effectiveness in sustainable living. In this study, this is the role of the association that promotes aluminum packaging recycling in Spain (Arpal). Arpal provides people as facilitators and program developers. Experts from Arpal can also provide additional knowledge and active methodology so that teachers become sustainability leaders within their schools. According to Kennelly, Taylor, and Maxwell [40], when values and beliefs about the issues associated with sustainability are strong, they become part of the teacher's identity and provide a personal motivation to incorporate those values into their teaching.

All of the ideas and knowledge obtained from a review of the literature were considered in the research that follows.

\section{Materials and Methods}

The goal of this research was to study whether the teaching unit could contribute to fostering recycling habits in early childhood. As has been said before, usually verbal persuasion is not enough to 
encourage children to act positively to protect the environment [41]. Moreover, it seems that one of the most crucial challenges in education for sustainable development is didactic [42]. Thus the researchers thought that a teaching unit with active learning activities that develop under multiple skills could have a better impact on children's behavior by focusing on a concrete sustainable practice: aluminum packaging recycling.

The teaching unit was designed by seven teachers that were then responsible for the implementation of a pilot test developed in two preschools in Córdoba and one in Seville (with an average of 18 children in each preschool) to assess its efficacy. The teachers belonged to the association Supla (http://suplasl.es), which promotes social and solidarity economy. The research took place with the collaboration of Arpal, which was in charge of training teachers in aluminum packaging recycling issues and of the supervision of technical issues related to the content of aluminum. On the other hand, the impact that the teaching unit had on the preschools and the families was also evaluated. After this exploratory research, the teaching unit was implemented in 29 Andalusian preschools, with a total of 1300 children participating in the study.

\subsection{Phases and Research Tools}

\subsubsection{Diagnosis}

The goal of the first phase was to find out the level of knowledge, awareness, and behavior that children under 6 years old (mainly 2 and 3 years old), parents, and teachers had before the program.

For the teachers, a questionnaire was prepared to assess three parameters: four questions tested knowledge about recycling and about aluminum packaging, three about awareness, and two about behavior. This questionnaire was answered before the training that Arpal offered to teachers in November 2017. The survey questions included the following:

Q1: Do you know what material goes into recycling containers that are green, yellow, and blue?

Q2: Can you mention packaging made of aluminum?

Q3: Do you know in which container aluminum packaging must be placed in order to be recycled?

Q4: How important do you consider your participation in aluminum packaging recycling to be?

Q5: Why do you consider your participation in aluminum packaging recycling important (or not)?

Q6: Who benefits if you recycle aluminum packaging?

Q7: Do you recycle some of the following materials at home or in the workplace: beverage cans, bricks, aluminum packaging, foil paper, or other packaging made of metal?

Q8: Do you teach about waste recycling in the classroom?

Q9: Have you ever heard about a circular economy?

To determine children's knowledge, teachers tested five parameters at the beginning of the teaching unit: knowledge of the containers for recycling, attitudes toward recycling, creativity when working with recycled material, the classification of packaging before recycling, and knowledge about where aluminum packaging must be placed in order to be recycled. They retested the same parameters at the end of the teaching unit.

Concerning parents, the research of Ballantyne, Fien, and Packer [43] was followed. In that study, some parents announced that talking about environmental topics can help modify children's attitudes and behaviors. In addition, Grodziéska-Jurezask et al. [44] showed that the behaviors of parents have a significant impact on children's knowledge of and attitudes toward the environment. For these reasons, the preschool sent a letter to the parents informing them about the teaching unit. Families were invited to participate in the activities with their children and were asked to reinforce recycling habits at home. A questionnaire was also distributed among the parents that participated in the program as volunteers. The survey questionnaire had eight questions: the first seven were the same that were used in the questionnaire to teachers. Question number eight asked, “Do you teach about waste recycling to your 
child?" Question number nine was deleted. Moreover, parents also received an observation sheet to share information about their children's attitudes at home during the exploratory study.

\subsubsection{Implementation}

First, a teaching unit about aluminum packaging recycling for children under 6 years old was developed by the teachers (February to May 2018). Once the draft was completed, researchers and Arpal reviewed it and made the required adjustments. Second, a pilot test of the teaching unit was developed over two weeks in three Supla preschools in Córdoba and Seville, with 54 children participating in total (June 2018).

The sample was a directed one and was not probabilistic, meaning that it was created depending on the availability of the children. Another factor considered was parents' willingness to have their children attend the teaching unit.

Table 1 shows the learning activities of the teaching unit.

Table 1. Activities of the teaching unit. Source: authors.

\begin{tabular}{|c|c|c|}
\hline Day & Active Learning Strategies & Learning Activities \\
\hline 1 & Initial activity: talking about recycling in general & $\begin{array}{l}\text { Brainstorming } \\
\text { Promoting ideas } \\
\text { Assembly }\end{array}$ \\
\hline 2 & $\begin{array}{c}\text { Knowledge activity and awareness: talking about colors of } \\
\text { containers for recycling and what to throw in each one. } \\
\text { Creation of a "Recycling Corner" with boxes and colors. } \\
\text { See Figure A1. }\end{array}$ & $\begin{array}{l}\text { Discussions within the class } \\
\text { Knowledge through action }\end{array}$ \\
\hline 3 & $\begin{array}{c}\text { Selecting different packaging and throwing it in the right } \\
\text { container. See Figure } \mathrm{A} 2 .\end{array}$ & Classification workshop \\
\hline 4 & 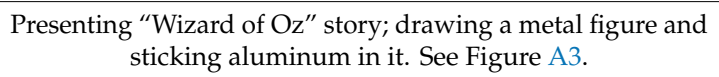 & $\begin{array}{l}\text { Creative workshop } \\
\text { Interacting with their friends }\end{array}$ \\
\hline 5 & $\begin{array}{l}\text { Selecting aluminum and metal packaging with a magnet. } \\
\text { See Figure A4. }\end{array}$ & Experimentation workshop \\
\hline 6 & $\begin{array}{l}\text { Out-of-class activities: seeing containers in the street and } \\
\text { throwing aluminum packaging in the yellow container. }\end{array}$ & $\begin{array}{l}\text { Experiential visit in collaboration } \\
\text { with parents }\end{array}$ \\
\hline 7 & $\begin{array}{l}\text { Creating a flowerpot with aluminum packaging, adding } \\
\text { seeds, and watering it. See Figure A5. }\end{array}$ & Creative and experimentation workshop \\
\hline 8 & $\begin{array}{l}\text { Painting and drawing on aluminum foil with different tools } \\
\text { (sponge, roller, and brush). See Figure A6. }\end{array}$ & Art and experimentation workshop \\
\hline 9 & $\begin{array}{l}\text { Interacting with their teacher and friends: seeing and } \\
\text { touching bauxite stone. }\end{array}$ & $\begin{array}{l}\text { Sensory workshop (observation, } \\
\text { manipulation, etc.). }\end{array}$ \\
\hline 10 & $\begin{array}{c}\text { Designing a circuit made of aluminum packaging and other } \\
\text { materials such as balls, strings, etc.; imitating characters of } \\
\text { "Wizard of Oz" story. See Figure A7. }\end{array}$ & $\begin{array}{l}\text { Dramatization } \\
\text { Creative and psychomotor workshop }\end{array}$ \\
\hline 11 & $\begin{array}{l}\text { Out-of-class activity: visit to the recycling center in Sadeco. } \\
\text { See Figure A8. }\end{array}$ & $\begin{array}{l}\text { Experiential visit in collaboration } \\
\text { with parents }\end{array}$ \\
\hline 12 & $\begin{array}{c}\text { Creating a "hungry hungry hippos" toy and throwing balls } \\
\text { made of aluminum packaging. }\end{array}$ & $\begin{array}{l}\text { Creation } \\
\text { Gamification } \\
\text { Playing }\end{array}$ \\
\hline 13 & Designing a collar made of aluminum caps. & Art workshop \\
\hline 14 & $\begin{array}{l}\text { Interacting with their teacher and friends: puppet show } \\
\text { about "Wizard of Oz" story. }\end{array}$ & Dramatization \\
\hline 15 & $\begin{array}{l}\text { Final activity: repeating the initial activities to assess the } \\
\text { learning process. }\end{array}$ & $\begin{array}{l}\text { Brainstorming } \\
\text { Assembly }\end{array}$ \\
\hline
\end{tabular}

\subsubsection{Assessment}

The current study employed both qualitative and quantitative methods. The quantitative methods (a questionnaire and statistical analysis) were used to assess teachers' and parents' levels of knowledge, awareness, and actions regarding recycling before and after the program. The qualitative methods (collecting and analyzing data from observations, focus groups, and in-depth interviews) were used to 
assess changes in the children's behavior, the impact that the program had in the preschools, and a general evaluation of what the teachers and families made of the whole program according to their previous expectations.

Accordingly, an assessment was carried out at four levels: teachers, children, families, and preschool. First, researchers evaluated the knowledge that teachers had before and after the training on aluminum packaging (November 2017). Second, the teaching unit included tools to evaluate knowledge, awareness, and actions regarding recycling in children. Third, and concerning parents, pre- and post-questionnaires were distributed among them to discover their level of knowledge about recycling, their awareness, and their behavior. Due to the small number of post-questionnaires, an in-depth interview was also conducted in order to assess parents' attitudes toward the experience and children's attitudes toward recycling at home. According to Seidman, "In-depth interviewing's strength is that through it we can come to understand the details of people's experience from their point of view" [45] (p. 112).

Finally, for a more in-depth picture of the implementation of the teaching unit and how it impacted the education community, a focus group was carried out with both teaching and nonteaching staff from the preschool at the end of the activity. As a result, researchers could gain a better understanding of how the new activity was accepted; the degree of collaboration within the education community, parents, and children; or changes that were introduced.

\subsection{Methodology Used in the Statistical Analysis}

On the basis of the data obtained in the surveys carried out with parents and teachers, the results were analyzed and translated. For this, a series of steps was followed. First, the information obtained was classified into two groups: information collected prior to the training and information obtained once the recycling program had already taken place. Subsequently, each of these groups was divided into responses from parents of students and responses from the teachers at the preschools.

Once all the information was organized, each of the questions and the corresponding answers were addressed to tabulate the answers obtained in each question. The biggest difficulty encountered in this step was to establish a criterion to group the wide variety of responses to some open questions (e.g., "Do you know about aluminum packaging?") into more concrete values so that the table, the graphs, and the subsequent results were as simple and clear as possible. On the other hand, the questions that required a specific response (e.g., "value the importance of recycling between 0 and 10 ") were much easier to tabulate, since there was no need to interpret or establish a subjective criterion to classify the different responses.

Once each of the questions and their corresponding answers were tabulated, the results of the tables (the number of people choosing a certain answer) were transformed into percentages in order to translate them into graphs.

Finally, with the results of the tables already in percentages, the graphs were made. Once all of the tables and their corresponding graphs were finished, the statistical analysis was completed.

In summary, Table 2 describes all of the steps of the research, the groups involved, and the dates and activities used: 
Table 2. Steps, groups involved, dates, and techniques that were used in the research. Source: authors.

\begin{tabular}{|c|c|c|c|}
\hline Steps & Groups Involved & Date & Actions \\
\hline $\begin{array}{l}\text { Cooperation agreement and } \\
\text { working plan }\end{array}$ & $\begin{array}{l}\text { Arpal association } \\
\text { Supla association }\end{array}$ & $\begin{array}{c}\text { June } 2017 \\
\text { September-October } 2017\end{array}$ & $\begin{array}{l}\text { Meetings } \\
\text { Brainstorming } \\
\text { Commitment }\end{array}$ \\
\hline Training of teachers & $\begin{array}{l}\text { Seven teachers from Córdoba } \\
\text { and Seville and Arpal }\end{array}$ & November 2017 & $\begin{array}{l}\text { Lecture and active session } \\
\text { about aluminum packaging } \\
\text { and its recyclability }\end{array}$ \\
\hline $\begin{array}{l}\text { Pre- and post-assessment of } \\
\text { knowledge, awareness, and } \\
\text { actions regarding recycling }\end{array}$ & Seven teachers & November 2017 & $\begin{array}{l}\text { Quantitative: } \\
\text { Questionnaire pre- and } \\
\text { post-training }\end{array}$ \\
\hline $\begin{array}{l}\text { Design of a teaching unit } \\
\text { about aluminum packaging } \\
\text { recycling for children under } 6 \\
\text { years old }\end{array}$ & Teachers and Arpal & February-May 2018 & $\begin{array}{l}15 \text { active learning activities } \\
\text { involving children, volunteer } \\
\text { parents, and the neighborhood }\end{array}$ \\
\hline $\begin{array}{l}\text { Find out the pre-level of } \\
\text { knowledge, awareness, and } \\
\text { actions regarding recycling }\end{array}$ & $\begin{array}{l}\text { Parents of } 54 \text { children in } \\
\text { Córdoba and Seville }\end{array}$ & 1-10 June 2018 & $\begin{array}{c}\text { Quantitative: pre-activity } \\
\text { questionnaire }\end{array}$ \\
\hline $\begin{array}{l}\text { Implementation of the } \\
\text { teaching unit in a pilot test }\end{array}$ & $\begin{array}{c}\text { Two preschools in Córdoba, } \\
\text { one in Seville ( } 54 \text { children in } \\
\text { total): Centro de Ed Inf Supli } \\
\text { Sur (Córdoba), Centro de Ed } \\
\text { Inf Supli Levante (Córdoba), } \\
\text { and Centro de Ed Inf Supli } \\
\text { Sevilla (Seville) }\end{array}$ & 11-22 June 2018 & $\begin{array}{l}\text { Active learning fostering } \\
\text { multiple intelligences } \\
\text { Observation } \\
\text { Parents' participation }\end{array}$ \\
\hline $\begin{array}{l}\text { Assessment of the pilot test } \\
\text { Review of the initial teaching } \\
\text { unit and realization of the final } \\
\text { teaching unit }\end{array}$ & Seven teachers & 23 June-7 July 2018 & $\begin{array}{c}\text { Observations of } \\
\text { teachers/development of } \\
\text { activities/observations from } \\
\text { parents }\end{array}$ \\
\hline $\begin{array}{l}\text { Assessment of how the } \\
\text { program affected the } \\
\text { whole family }\end{array}$ & $\begin{array}{l}\text { Parents of } 54 \text { children in } \\
\text { Córdoba and Seville }\end{array}$ & $\begin{array}{l}23 \text { June-7 July } 2018 \\
9 \text { July } 2018\end{array}$ & $\begin{array}{c}\text { Quantitative: } \\
\text { post-questionnaires and } \\
\text { in-depth interview }\end{array}$ \\
\hline $\begin{array}{l}\text { Final assessment of the } \\
\text { program and its impact on the } \\
\text { preschool community }\end{array}$ & Teachers and managers & 10 July 2018 & $\begin{array}{l}\text { Qualitative: } \\
\text { focus group }\end{array}$ \\
\hline $\begin{array}{l}\text { Implementation of the final } \\
\text { teaching unit }\end{array}$ & $\begin{array}{c}29 \text { preschools in Córdoba and } \\
\text { the Cádiz region (1300 } \\
\text { children) }\end{array}$ & $\begin{array}{l}7 \text { July } 2018 \text { to the end of } \\
\text { the month }\end{array}$ & $\begin{array}{l}\text { Active learning fostering } \\
\text { multiple intelligences }\end{array}$ \\
\hline
\end{tabular}

The research protocol was submitted for consideration, comment, and approval to the managers of the preschool. Moreover, each family was adequately informed of the aims, the methods, any possible conflicts of interest, the institutional affiliations of the researchers, the anticipated benefits of the study and the discomfort it may entail, and any other relevant aspects of the study. All subjects gave their informed consent for inclusion before they participated in the study.

\section{Results}

\subsection{Results of the Qualitative Assessment}

\subsubsection{Teachers' Observations}

All teachers agreed that the teaching unit strongly motivated the children and that they performed the activities with great interest and curiosity. In spite of the young age of the children (under 6 years old and mainly 2 and 3 years old), they understood perfectly how to sort material according to a code and to distinguish aluminum from other materials. A deeper analysis of the activities revealed that all of them were very creative when they made handicrafts with recycled material. 


\subsubsection{Focus Group with Teachers}

The general opinion about the experience was very positive, and all teachers agreed that the teaching unit was very useful in demonstrating how and why to recycle aluminum packaging, not only for the children but also for the teachers and families. Furthermore, establishing a recycling culture in the preschool was seen as important: all of the teachers wanted to have a permanent "Recycling Corner" at the preschools. They also proposed the development of a teaching unit with all of the children of the preschool throughout the academic year.

In addition, both the teachers and the director of Supla (the association that manages the preschools) were convinced that the teaching unit increased the reputation of the preschools among parents, relatives, and neighbors.

All attendees highlighted the benefits of collaboration between the preschools and the recycling association Arpal. It was a win-win activity, and teachers pointed out that while working with Arpal, they could see that their teaching unit was part of a bigger project that covers the promotion of aluminum packaging recycling in all of Spain, which for them was very motivating.

Teachers highlighted that the children were very interested in all of the activities involved in the teaching unit. Some of the activities worked particularly well, such as the selection of packaging and asking the children to throw the packaging in the right container or the visit to the recycling center. Other activities, such as playing with the magnet to see what packaging gets stuck to it, or the necklace that children made with coffee caps, worked in one preschool but not in others.

Teachers suggested some revisions to the teaching unit. First, in terms of the best time to carry it out, May and June are not ideal months due to the hot weather in this part of Spain and the tiredness of children and teachers. After a short discussion, and taking into consideration that it is a long teaching unit (at least 15 days), teachers agreed that the best option would be to develop it during the greater part of the academic year, perhaps once per week. Secondly, they wanted to change the activity about the mineral bauxite because the children were bored, so a more interactive activity would be a better option. Third, and considering that some children still do not recognize colors at that age, there is a need to adapt the activities that talk about the color of the container in which to throw aluminum packaging. Despite that fact, small children paid attention to the drawings of the containers in order to learn which one was the right one. On the other hand, all of the teachers agreed that this activity was also very useful in teaching the color yellow. Fourth, this was a great chance to spread the message about recycling in the neighborhood (with only a slight change to some of the activities). Teachers proposed that when children go to throw aluminum packaging in the yellow container, they could carry messages about recycling that everybody could see, or they could wear costumes about this subject. In addition, they could carry messages inviting neighbors to use the recycling containers.

\subsubsection{In-Depth Interviews with Parents}

During an interview with one family, it was highlighted that children are now aware of recycling and about the containers in the street: "At home, we recycled before the activity and our son (3 years old) didn't pay attention to that or to the containers in the street. During and after the activity he was always asking about where he can throw different packaging — not only aluminum —and now he notices the containers in the street," explained the mother. Parents added that they had noticed a significant change in their children regarding the recycling process. Parents noticed that their children were asking questions about where they could recycle materials even though they knew the answer (to reinforce knowledge).

Besides that, and during the time that the activity was developed, children explained at home what they had done each day concerning the teaching unit on aluminum packaging recycling. Furthermore, parents believed that the activities of the teaching unit not only taught children to recycle, but also reinforced their ability to work in a group and act as a complement to the children's relationship with the environment. 
Another interesting issue was that, during the interview, parents asked questions about recycling that had nothing to do with the teaching unit, such as whether they have to wash aluminum packaging before throwing it into the yellow container or where to recycle some items. Due to that fact, the researchers believe that the parents were concerned about recycling and about "doing things in the right way".

Parents were sure that the teaching unit is an excellent idea for showing children how to recycle at early ages, but they believed that children's awareness should be continuous, rather than presented as a compulsory subject at the preschool. They proposed that the activities could last all academic year and that the preschool should be provided with a permanent "Recycling Corner".

\subsection{Results of the Quantitative Assessment}

\subsubsection{Teachers}

Teachers dramatically improved their knowledge of aluminum packaging recycling and, following the training, showed a strong determination to take aluminum packaging to the yellow container to recycle it. First, prior to the training, teachers could not identify examples of aluminum packaging other than beverage cans (only $16.67 \%$ of answers were correct). After the training, the number of correct answers increased dramatically, reaching $83.33 \%$.

Second, and regarding knowledge about recycling, the majority of teachers recognized that aluminum packaging should be taken to a yellow container (83.33\%). After the training, all of them answered correctly.

Third, all teachers gained awareness and personal responsibility about aluminum packaging recycling. Therefore, they also perceived more immediate personal benefits after the training, besides the global advantage concerning the planet in general (see Figure 2).

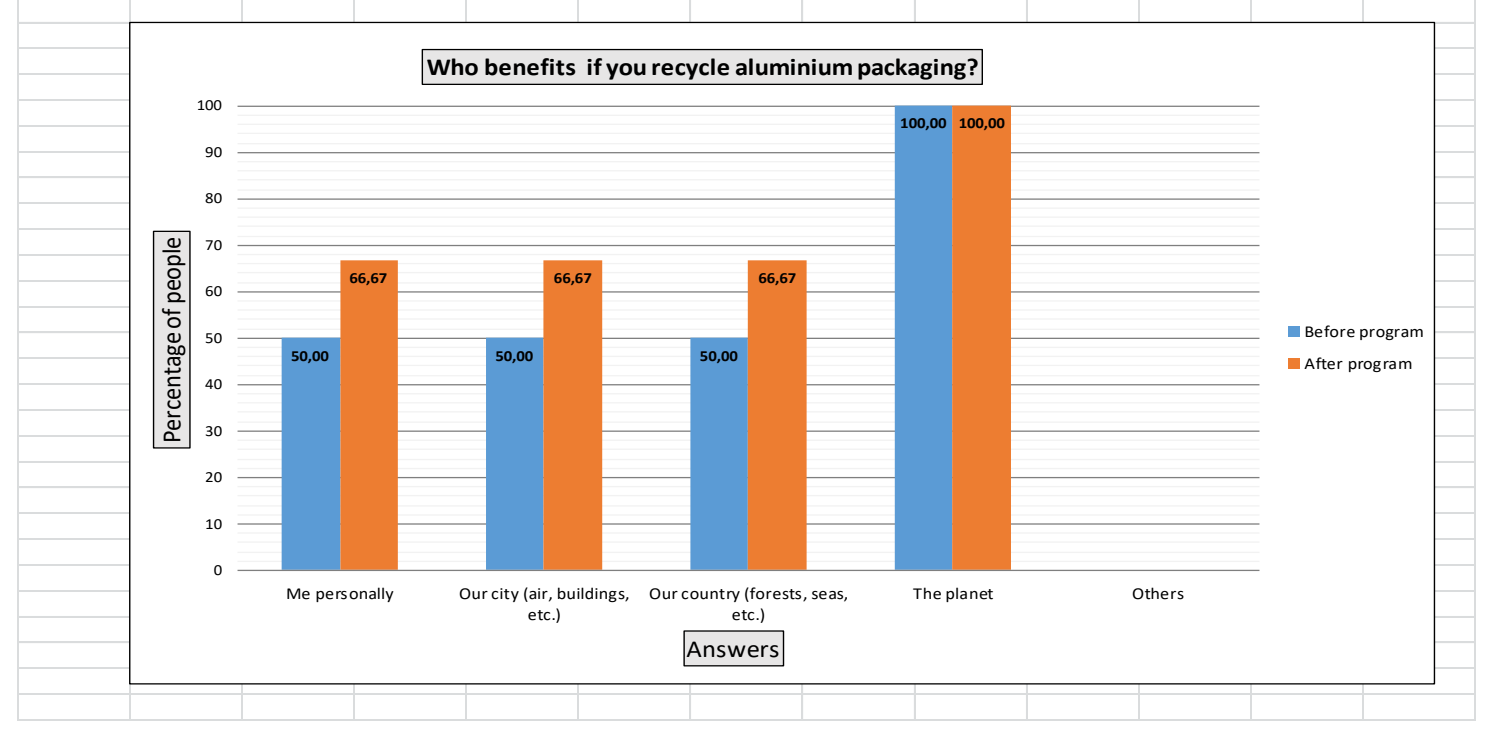

Figure 2. Answer to the question, "Who benefits if you recycle aluminum packaging?"

Finally, after the training, all teachers gave assurances that they will recycle aluminum packaging (see Figure 3). They will commit themselves to sustainability teaching in order to motivate their students (see Figure 4). Thus, teachers will try to make comments daily about waste recycling in the classroom, and they will develop activities to continue early education on sustainability. 


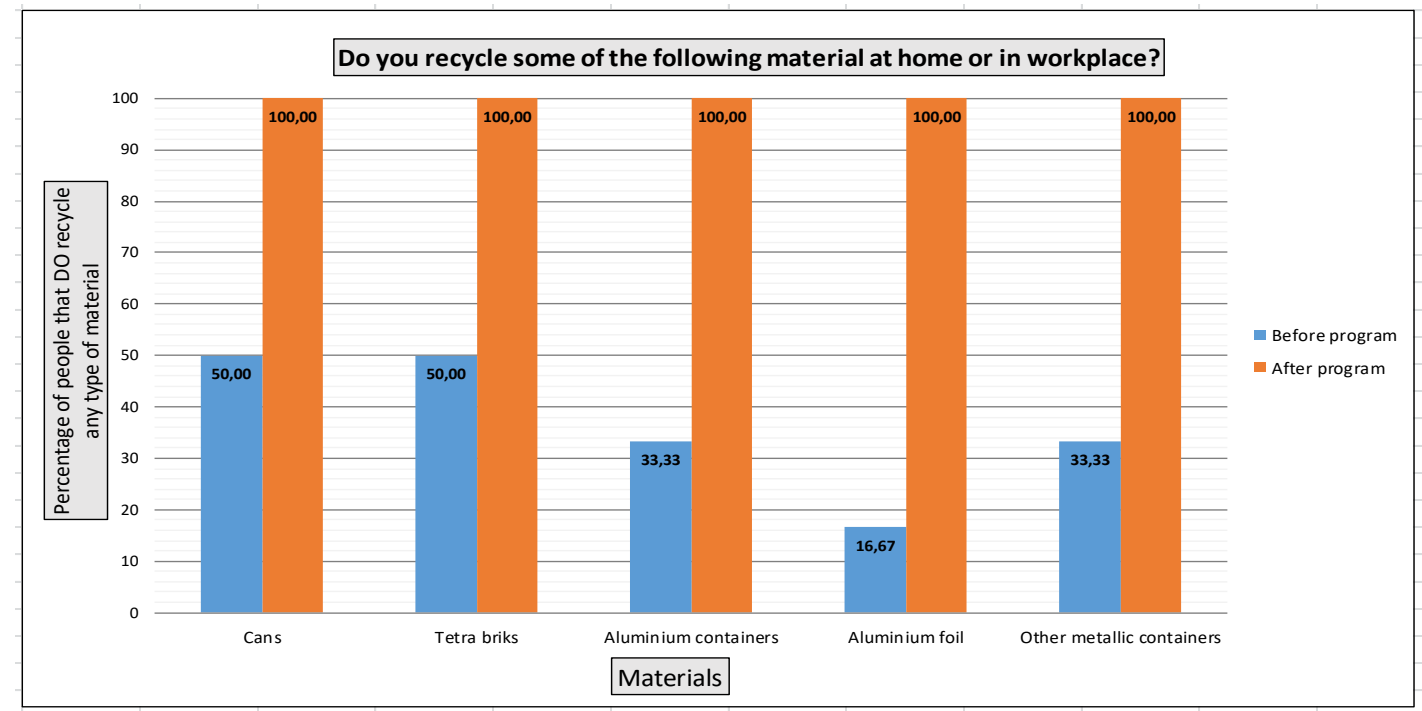

Figure 3. Answer to the question, "Do you recycle some of the following materials at home or in the workplace?"

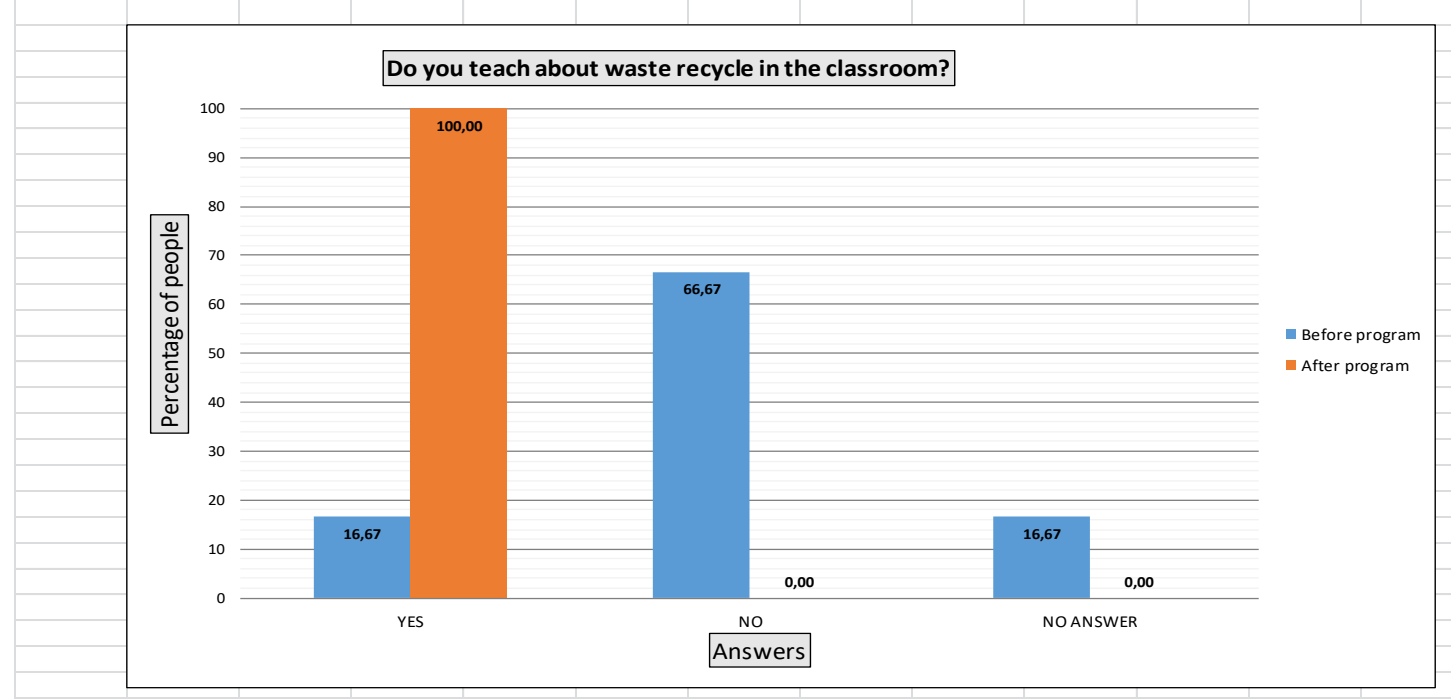

Figure 4. Answer to the question, "Do you teach about waste recycling in the classroom?"

\subsubsection{Parents}

The results of the study indicated that parents were influenced by the preschool, the teachers, and most of all their children. The preschools sent a letter to the parents informing them about the teaching unit, and they also asked the parents to answer a questionnaire before and after the program.

The quantitative analysis of these questionnaires showed that the influence of the project was very positive in the sense that parents gained both more knowledge of the subject and the motivation to recycle. First, there was a dramatic increase in the knowledge of flexible and semirigid aluminum packaging after the conclusion of the program (from $22.58 \%$ to $66.67 \%$ ), and all of the participants gave at least one correct answer (see Figure 5). 


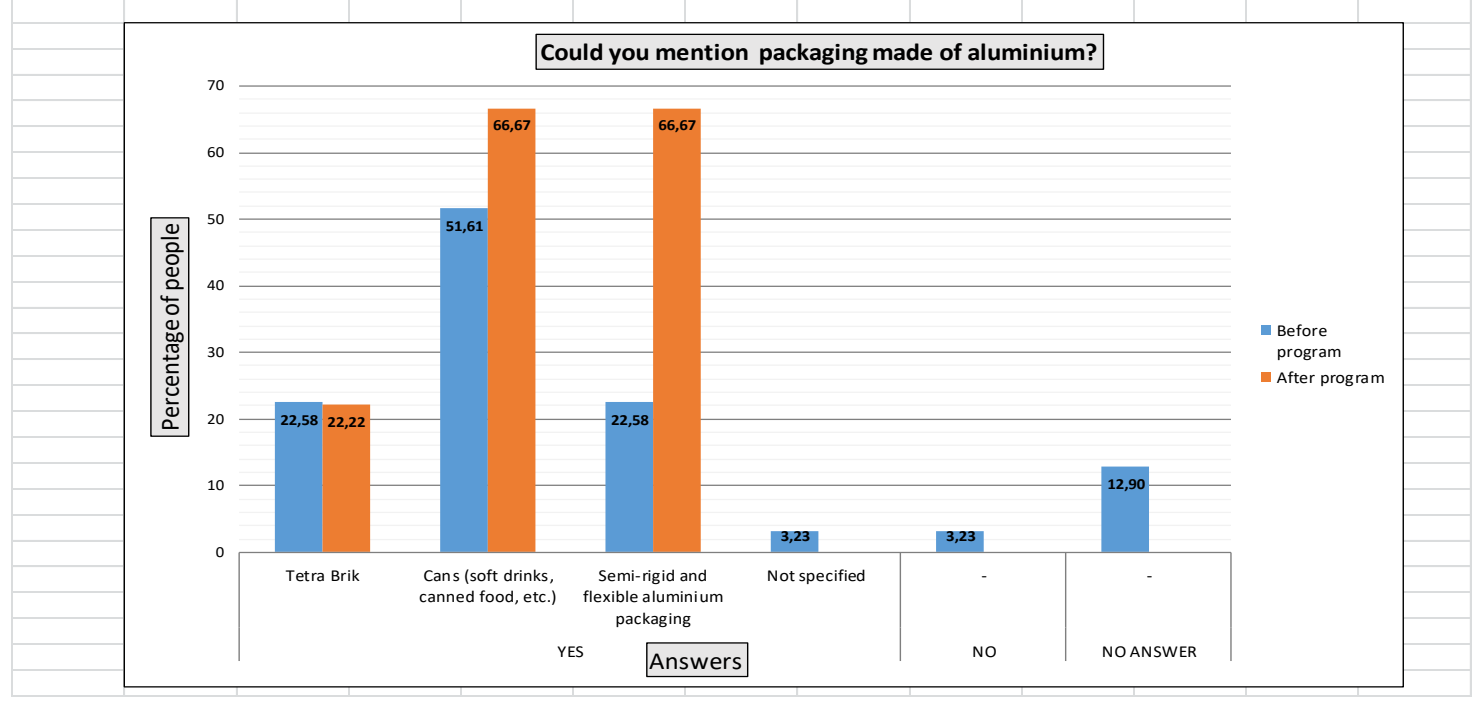

Figure 5. Answer to the question, "Could you mention packaging made of aluminum?".

Second, a great majority of the parents $(90 \%)$ had previous knowledge of the container in which aluminum packaging must be placed in order to be recycled. After the program, all of them answered this correctly.

Third, researchers noticed that the answers showed an increase in the level of importance given to the recycling process through their participation (see Figure 6). In addition, the parents indicated that after the program they taught their children how to recycle $(100 \%)$. They would talk about waste recycling at home, ask their children to throw the waste in the right bin at home, and go with their children to the containers as a daily routine.

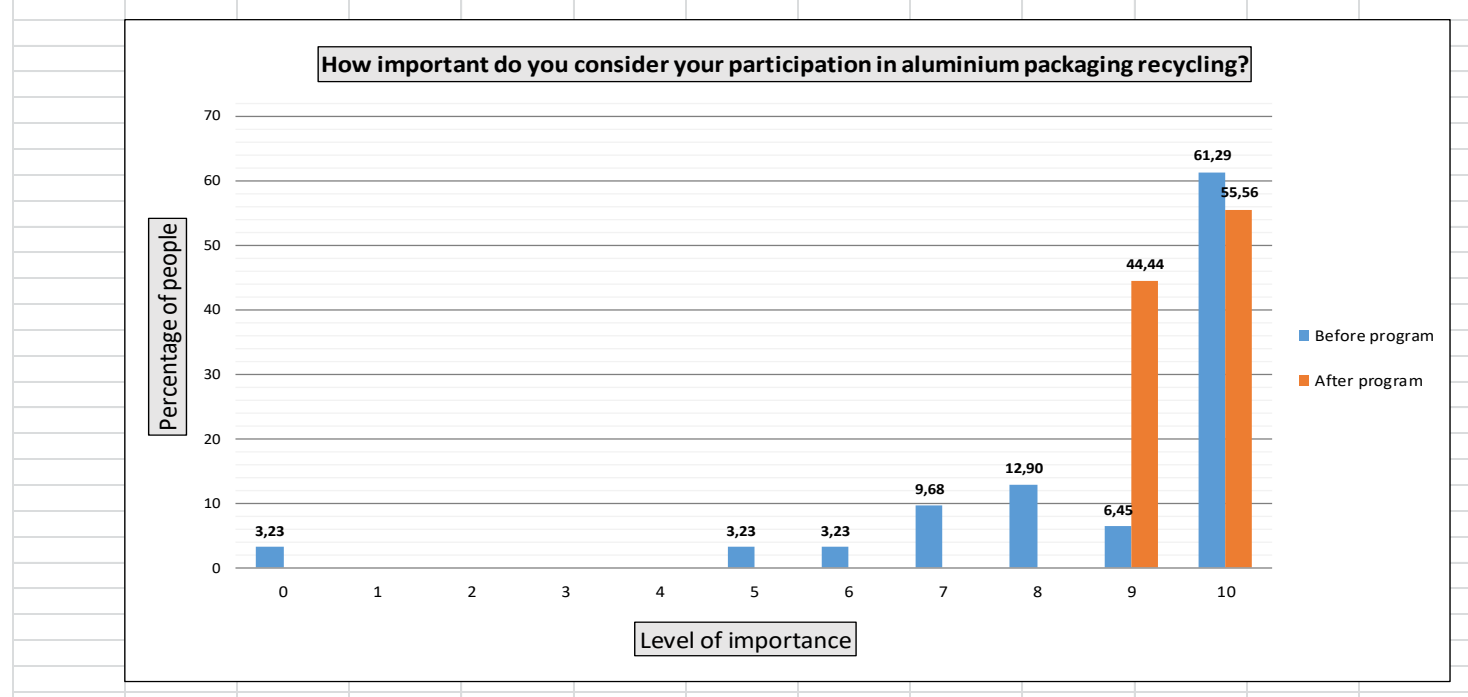

Figure 6. Answer to the question, "How important do you consider your participation in aluminum packaging recycling to be?"

Fourth, parents considered the more immediate benefits of recycling, switching from "the planet" to "our city" or "me personally" (see Figure 7). This aspect could convince them to recycle and help establish a sustainability culture, as can be seen in Figure 8, where it is shown clearly that the number of parents and the materials that they recycle increased, primarily in terms of aluminum semirigid and flexible packaging (containers), aluminum foil, and other packaging made of metal. 

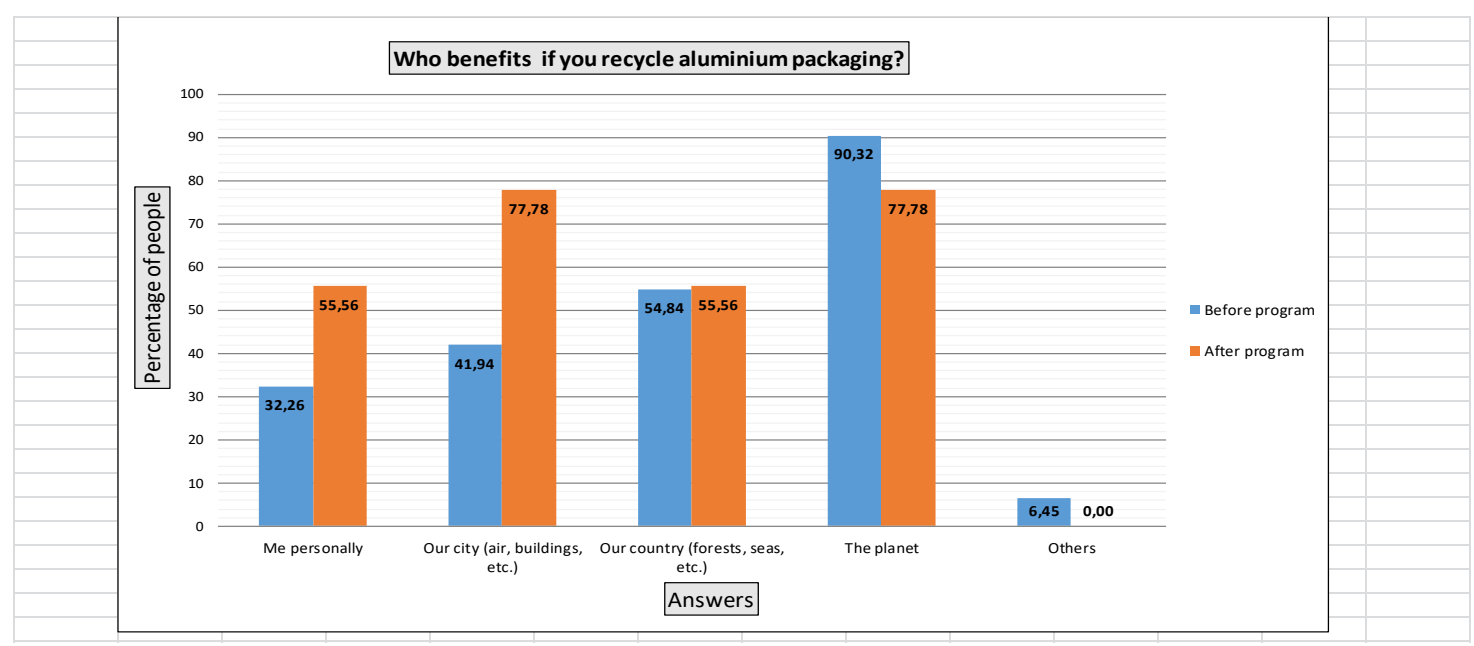

Figure 7. Answer to the question, “Who benefits if you recycle aluminum packaging?"

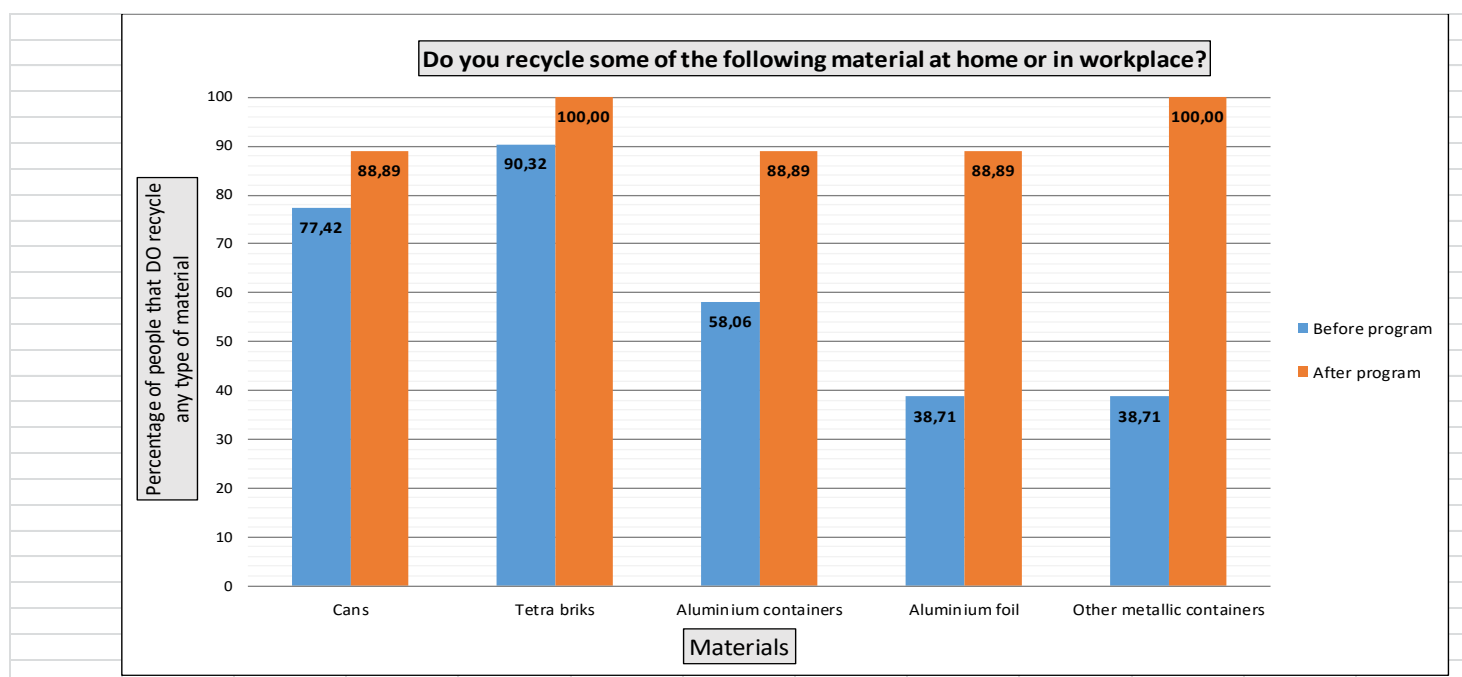

Figure 8. Answer to the question, "Do you recycle some of the following materials at home or in the workplace?"

Finally, after the implementation of the teaching unit, all parents answered that they would teach their children to recycle.

\section{Conclusions}

Regarding the aim of this study, which was to define and implement a teaching unit on sustainability for early childhood education by focusing on concrete sustainable practices (aluminum packaging recycling), the results allowed the researchers to declare that the activities achieved very positive results, both with the children and with all of the agents who contributed to the program. In fact, all parties involved have now learned about aluminum packaging recycling, make use of it, and are very motivated to continue recycling.

This study found that different partners, such as teachers, children, parents, preschools, and associations, can work together with the common goal of developing a sustainable practice, and all of them benefit from this collaboration. The researchers would like to highlight that the collaboration of an industrial association (Arpal) with the educational community can achieve good results in working for a more sustainable world, and that each of them can benefit from the knowledge, skills, and practices of the other. 
In addition, this study illustrates the impact that early childhood education on environmental issues can have on children, families, and the broader community, as proposed by Davis [12]. The teaching unit developed became the core value upon which all teaching was based, and this view influenced the preschool center, the children, and the families. The preschools gained an image of being "environmentally friendly" thanks to the activity and because they now have a permanent "Recycling Corner". In addition, preschools have now included the teaching unit in their activities with new children each year. Parents now have a greater feeling of belonging to the community and being more involved in the education of their children. Teachers are now very motivated to continue teaching recycling and to create new materials and activities for children. In summary, education on sustainable development in early childhood encourages the importance of recognizing the interdependency of adults and children in addressing environmental challenges [46]. This study showed the success of collaborations, improved relationships within the preschool community, and increased parents' involvement.

At the same time, the research affected both the teaching and learning process: the quality of teaching improved via the introduction of innovative methodologies and activities [47,48], and these methodologies increased the participation of children. It seems that one feature of the success of the program was related to active learning.

In addition, the teachers produced curricular materials related to sustainability that can be used in other educational settings, which expanded the habit of recycling in a snowball process to other preschools and communities. In this sense, the teaching unit has been incorporated into the syllabus of the 3 centers that performed the pilot test and in the 29 others that implemented it after the research.

Finally, this study points out the necessity of continuing to train teachers in sustainability, as Aznar et al. have pointed out $[49,50]$. This study confirms that teachers appreciate collaboration (e.g., providing them with knowledge and materials) that will help them to design activities to educate young children on sustainability in Spain. In this sense, this study illustrates the barriers that still exist between teachers and staff to implementing early childhood education on sustainability, such as time or resources. As education on sustainability in early childhood teacher education is sometimes marginalized in favor of primary and secondary teacher education [48], the researchers suggest dedicating time and effort to early childhood teacher training on environmental and sustainability issues. Concerning parental barriers, this study confirmed that parents discover their children as agents of change for sustainability, so it is necessary to make them more aware of this role.

In conclusion, this study shows that a broad cultural shift has occurred toward sustainability in preschools, families, and children, and that it is still necessary to develop environmental education programs directed toward very young children (under 6 years old).

On the other hand, this study had some limitations, and some features of the early childhood sustainable education program merit further investigation. First, due to time limits and the characteristics of the material, the research focused on only one environmental topic: the recycling of aluminum packaging. Future research could be conducted focusing on further environmental topics. Second, the study focused primarily on the opinions, perceptions, and actions of the teachers, the children, and their parents, so this study did not involve other voices from the community directly in the data. Finally, while the sustainable practices achieved very positive results, this conclusion does not mean that the effects will last forever, and the researchers think that it is necessary to continue with the efforts, applying similar actions every academic year.

Author Contributions: This paper is the result of teamwork. P.B., O.R.-L., and M.T. conceived of the research. O.R.-L. designed the methodology and processed the data. P.B., O.R.-L., and M.T. analyzed the data. P.B., O.R.-L., and M.T. discussed the results. P.B. wrote the original draft preparation. P.B., O.R.-L., and M.T. wrote the final version.

Funding: This research received no external funding.

Acknowledgments: The authors are grateful to the teachers, students, and parents who participated in this study. The authors would also like to thank ARPAL (the association that promotes aluminum packaging recycling in 
Spain) and SUPLA Educational Services, who helped with the development of the program. We would also like to thank Frederic Marimon and research assistant José Schöder for their collaboration.

Conflicts of Interest: The authors declare no conflicts of interest.

\section{Appendix A}

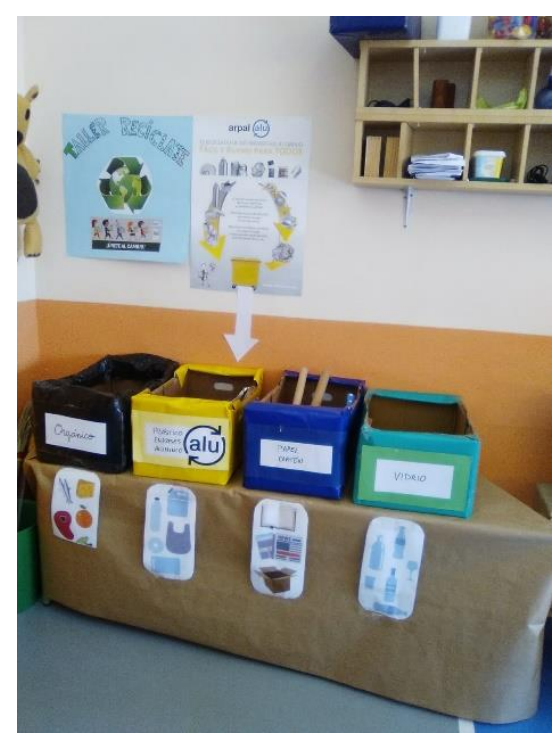

Figure A1. Creation of a "Recycling Corner".

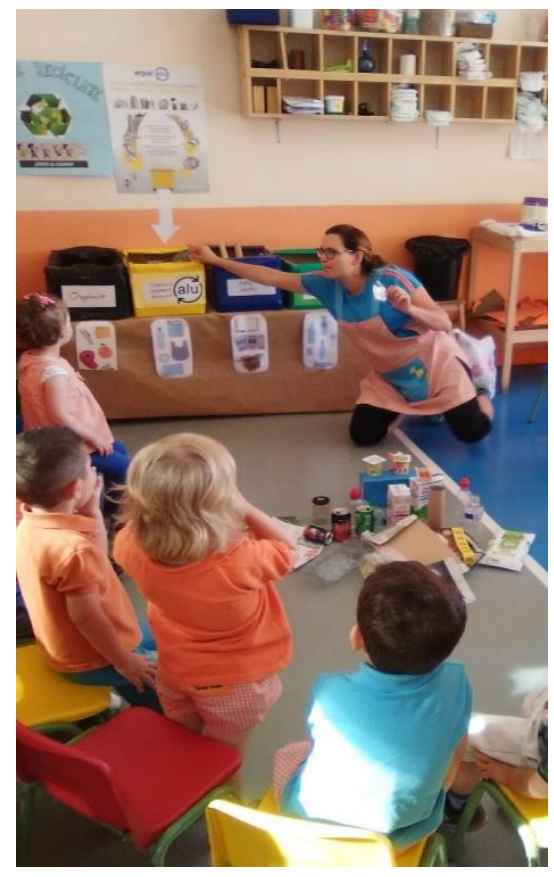

Figure A2. Selecting different packaging and throwing it in the right container. 


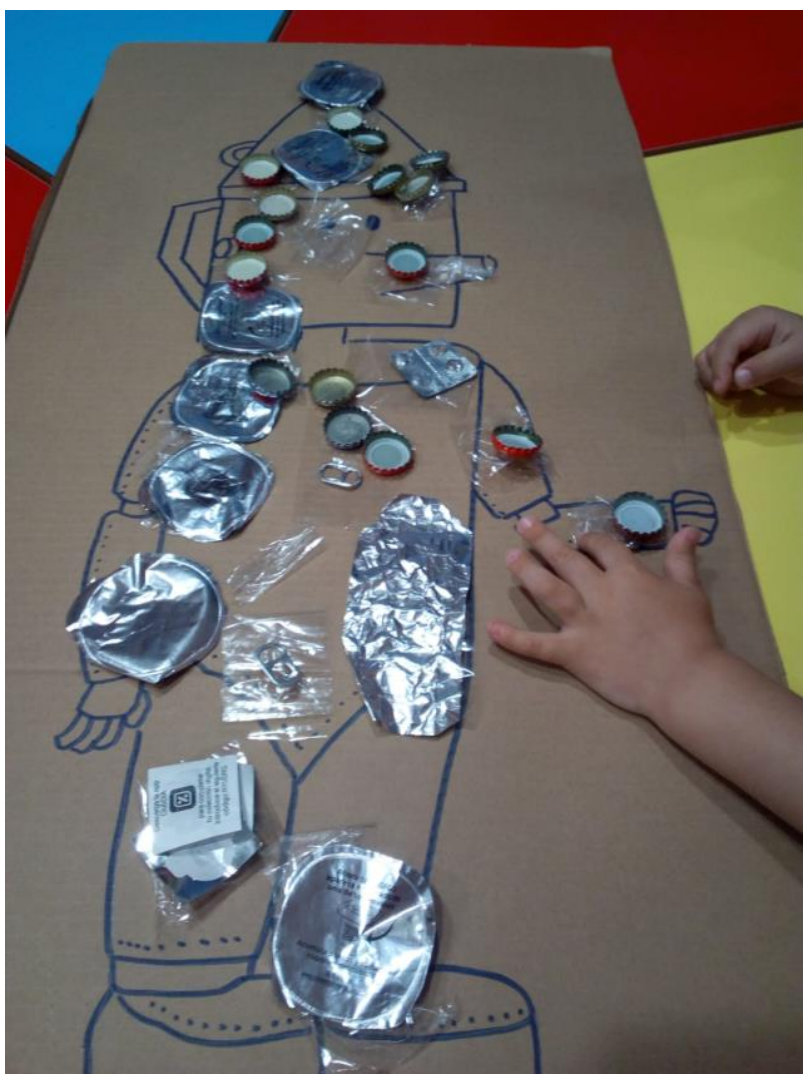

Figure A3. Drawing a metal figure and sticking aluminum on it.

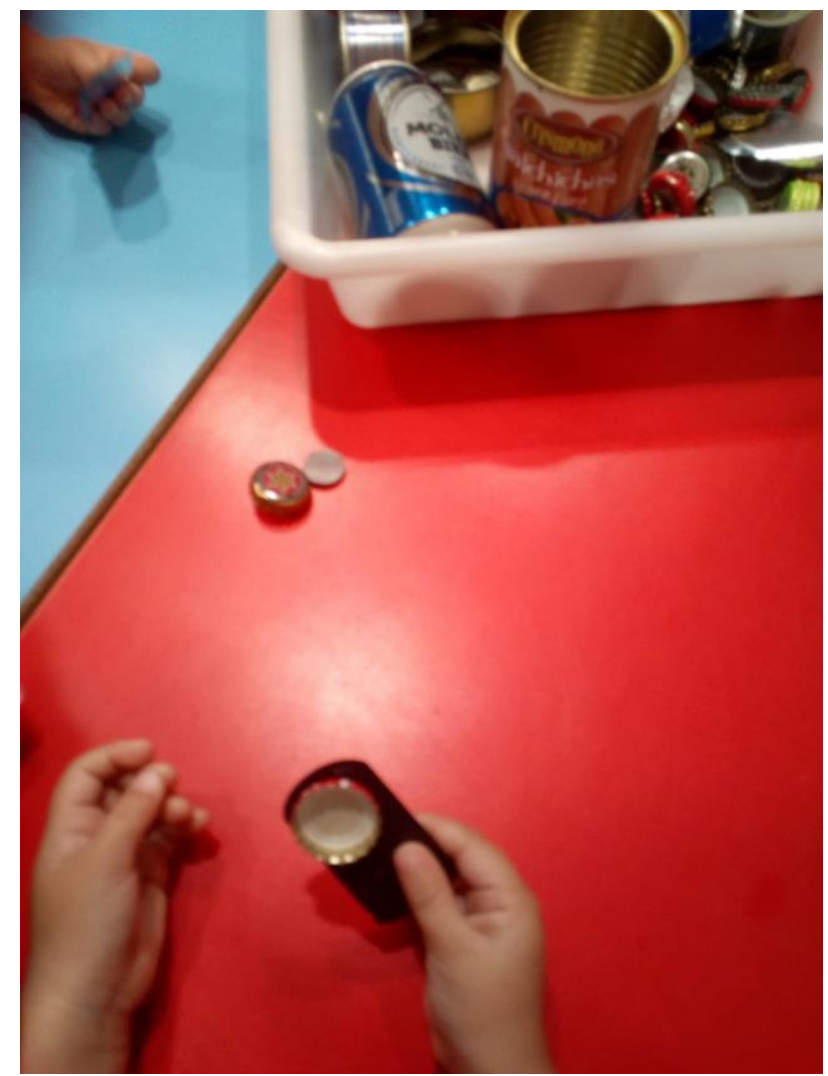

Figure A4. Selecting aluminum and metal packaging with a magnet. 


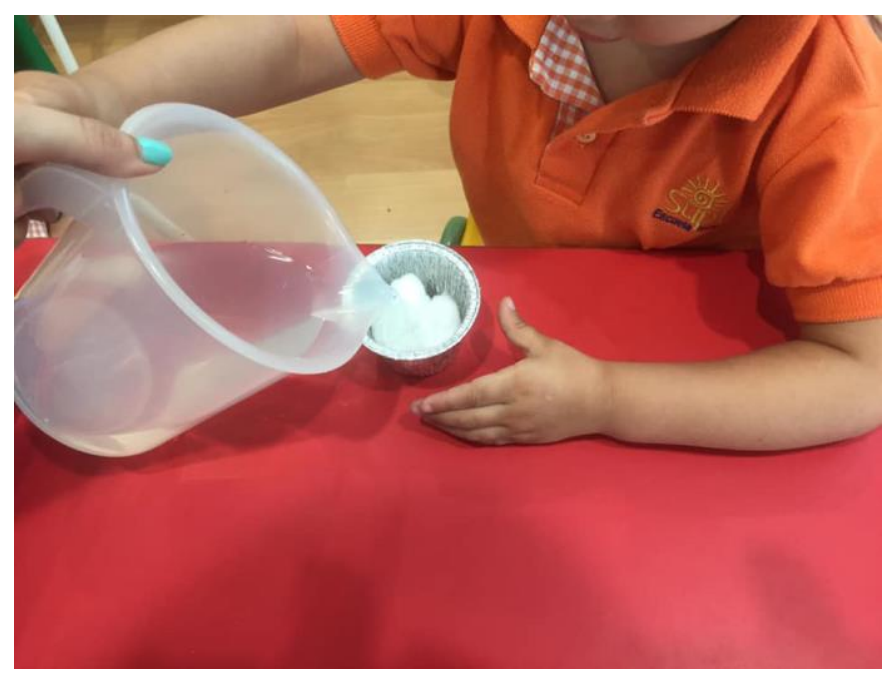

Figure A5. Creating a flowerpot with aluminum packaging, adding seeds, and watering it.

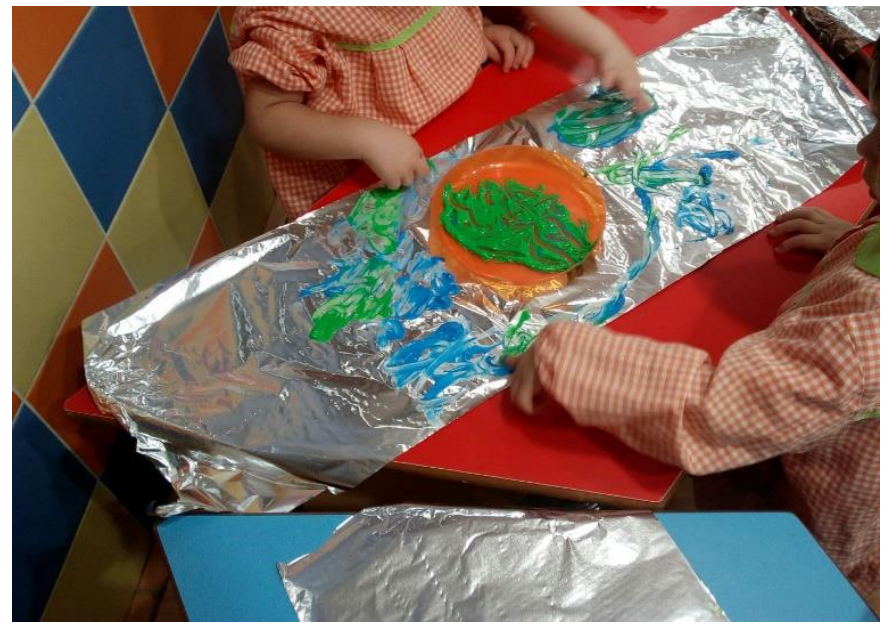

Figure A6. Painting and drawing on aluminum foil with different tools.

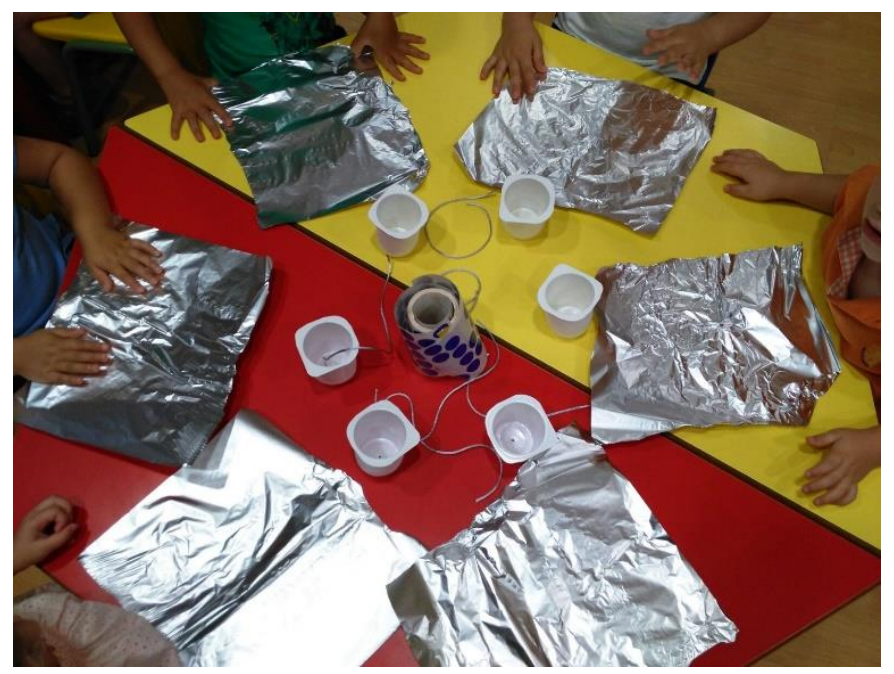

Figure A7. Designing a circuit made of aluminum packaging and other materials. 


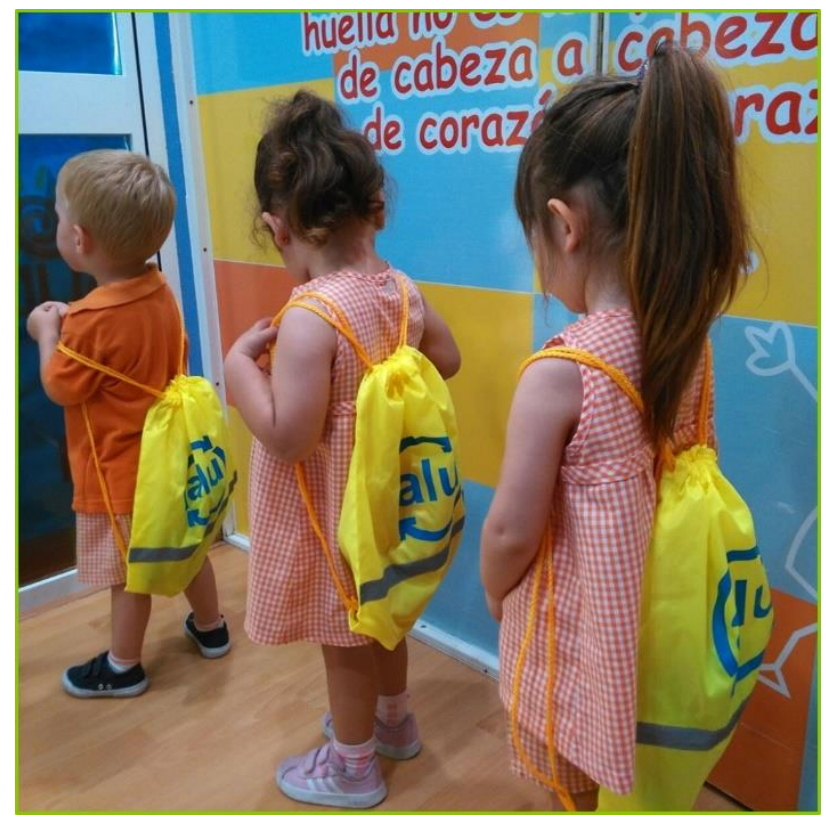

Figure A8. Visiting the recycling center.

\section{References}

1. United Nations. The Sustainable Development Goals Report 2016; United Nations: New York, NY, USA, 2016.

2. World Education Forum. Incheon Declaration and Framework for Action for the Implementation of Sustainable Development Goal 4: Education 2030: Towards Inclusive and Equitable Quality Education and Lifelong Learning for All; UNESCO: Paris, France, 2015.

3. United Nations. Transforming Our world: the 2030 Agenda for Sustainable Development; United Nations: New York, NY, USA, 2015; Available online: http://tinyurl.com/od9mens (accessed on 13 July 2018).

4. Peter, B.C.; Joseph, P.W.; Arjen, E.J.W. Envisioning Futures for Environmental and Sustainability Education; Wageningen Academic Publishers: Wageningen, The Netherlands, 2017.

5. Hopwood, B.; Mellor, M.; O’Brien, G. Sustainable Development: Maping Different Approaches. Sustain. Dev. 2005, 13, 38-52. [CrossRef]

6. Fien, J. Education for Sustainability. In Studying Society and Environment. A Guide for Teachers; Robert, G., Ed.; Thomson: South. Melbourne, Australia, 2004; pp. 184-200.

7. María, A.M.M. Educating for local development and global sustainability: An overview in Spain. Sustainability 2009, 1, 479-493. [CrossRef]

8. Julie, D.; Sue, E. (Eds.) Research in Early Childhood Education for Sustainability; Routledge: Abingdon/London, UK, 2014.

9. Bob, G.; Bill, H.; Geoff, O. Environment, economy and society: fitting them together into sustainable development. Sustain. Dev. 2002, 10, 187-196.

10. Khajuria, A. Resource efficiency: Progress and Challenges of 3Rs technologies and policies. WIT Trans. Ecol. Environ. 2016, 202, 57-60.

11. Iris, D. Making 'Place' for Ecological Sustainability in Early Childhood Education. Environ. Educ. Res. 2012, 18, 19-29.

12. Davis, J.M. oung Children and the Environment: Early Education for Sustainability; Cambridge University Press: Cambridge, UK, 2015.

13. Sawitri, D.R. Education for Sustainable Development: How Early is Too Early? Adv. Sci. Lett. 2017, 23, 2559-2560. [CrossRef]

14. Loubser, C.; Yahya, N.A.; Johann, D.; Abdul, N.A. The effectiveness of environmental education workshops for teachers, learners and schools in Malasya. Environ. Dev. Sustain. 2014, 16, 1163-1176. [CrossRef]

15. Young, W.; Kumju, H.; McDona, S.; Caroline, J.O. Sustainable consumption: Green consumer behaviour when purchasing products. Sustain. Devel. 2010, 18, 20-31. [CrossRef] 
16. Kollmuss, A.; Julian, A. Mind the Gap: Why do people act environmentally and what are the barriers to pro-environmental behavior? Environ. Educ. Res. 2013, 8, 239-260. [CrossRef]

17. Chang, Y.J.; Laura, S.; Matthias, F. Assessing Child Development: A Critical Review and the Sustainable Child Development Index (SCDI). Sustainability 2015, 7, 4973-4996. [CrossRef]

18. Davis, J. Revealing the research 'hole' of early childhood education for sustainability: A preliminary survey of the literature. Environ. Educ. Res. 2009, 15, 227-241. [CrossRef]

19. Somerville, M.; Carolyn, W. Sustainability Education in Early Childhood: An Updated Review of Research in the Field. Contemp Issues Early Child. 2015, 16, 102-117. [CrossRef]

20. Iliopoulou, I. How young children think they can act for the environment: the case of forest and waste. Education 2018, 46, 249-263. [CrossRef]

21. Directive (EU) 2018/852 of the European Parliament and of the Council of 30 May 2018 amending Directive 94/62/EC on packaging and packaging waste. Available online: https://eur-lex.europa.eu/eli/dir/2018/852/oj (accessed on 30 September 2018).

22. Varela-Losada, M.; Arias-Correa, A.; Pérez-Rodríguez, U.; Vega-Marcote, P. How Can Teachers Be Encouraged to Commit to Sustainability? Evaluation of a Teacher-Training Experience in Spain. Sustainability 2019, 11, 4309. [CrossRef]

23. Korkmaz, A.; Yildiz, T.G. Assessing preschools using the Eco-Schools program in terms of educating for sustainable development in early childhood education. Eur. Early. Child. Educ. Res. J. 2017, 25, 595-611. [CrossRef]

24. Svetina, M.; Istenič-Starčič, A.; Juvančič, M.; Novljan, T.; Šubic-Kovač, M.; Verovšek, S.; Zupančič, T. How children come to understand sustainable development: A contribution to educational agenda. Sustain. Dev. 2013, 21, 260-269. [CrossRef]

25. Pramling, S.I.; Carlsson, M.A. The playing learning child: Towards a pedagogy of early childhood. Scand. J. Educ. Res. 2008, 52, 52-641. [CrossRef]

26. Pramling, N.; Doverborg, E.; Samuelsson, I.P. Re-metaphorizing Teaching and Learning in Early Childhood Education Beyond the Instruction-Social Fostering Divide. In Nordic Social Pedagogical Approach to Early Years; Charlotte, R., Kragh-Müller, G., Eds.; Springer: Berlin, Germany, 2017. [CrossRef]

27. Samuelsson, I.P. Why we should begin early with ESD: The role of early childhood education. Int. J. Early. Child. Learn. 2011, 43, 103-118. [CrossRef]

28. Samuelsson, I.P. What is the future of sustainability in early childhood? In The Sage Handbook of Early Childhood Research; Ann, F., Sharon, L.K., Tisdall, E.K.M., Eds.; Sage: London, UK, 2016; pp. 502-516. [CrossRef]

29. Taylor, N.; Frances, Q.; Chris, E. Educating for Sustainability in Primary Schools: Teaching for the Future; Sense: Rotterdam, The Netherlands, 2015. [CrossRef]

30. Pramling Samuelsson, I.; Kaga, Y. The Contribution of early childhood education to a sustainable society. The Role of Early Childhood Education for a Sustainable Society, Göteborg, Sweden, 2007; UNESCO: Paris, France, 2008.

31. Mackey, G. To know, to decide, to act: The young child's right to participate in action for the environment. Environ. Educ. Res. 2012, 18, 473-484. [CrossRef]

32. Boyd, D. Early childhood education for sustainability and the legacies of two pioneering giants. Early Years 2018, 38, 227-239. [CrossRef]

33. Luff, P. Early childhood education for sustainability: Origins and inspirations in the work of John Dewey. Education 2018, 46, 447-455. [CrossRef]

34. Edwards, S.; Cutter-Mackenzie, A. 'Next Time We Can Be Penguins': Expanding the Concept of 'Learning Play' to Support Learning and Teaching about Sustainability in Early Childhood Education. In Varied Perspectives on Play and Learning: Theory and Research on Early Years Education; Ole, F.L., Sue, D., Bob, P., Eds.; Information Age Publishing: Charlotte, NC, USA, 2013; pp. 255-274.

35. Samuelsson, I.P.; Park, E. How to Educate Children for Sustainable Learning and for a Sustainable World. Int. J. Early. Child. 2017, 49, 273-285. [CrossRef]

36. MacDonald, M. Early Childhood Education and Sustainability: A Living Curriculum. Child. Educ. 2015, 91, 332-341. [CrossRef]

37. Chauhan, S.; das, S.R.; Martin, H.; Natalia, R. Awareness vs Intentionality: Exploring Education for Sustainable Development in a British Hindu Community. Sustain. Dev. 2012, 20, 361-373. [CrossRef] 
38. Pollock, K.; Jane, D.W.; Peter, J.A. Inspiring environmentally responsible preschool children through the implementation of the National Quality framework: uncovering what lies between theory and practice. Aus. J. Early Child. 2017, 42, 12-19. [CrossRef]

39. Hopkins, C.; McKeown, R. Moving Beyond the EE and ESD Disciplinary Debate in Formal Education. J. Educ. Sustain. Dev. 2017, 1, 17-26. [CrossRef]

40. Kennelly, J.; Neil, T.; Maxwell, T. A student teacher's personal pathway to education for sustainability. Aust. J. Environ. Educ. 2008, 24, 23-33. [CrossRef]

41. Hsiao, C.Y.; Pei, Y.S. Exploring the effectiveness of picture books for teaching young children the concepts of environmental protection. Int. Res. Geogr. Environ. Educ. 2016, 25, 36-49. [CrossRef]

42. Buil-Fabregá, M.; Martínez, C.M.; Ruiz-Munzón, N.; Filho, W.L. Flipped Classroom as an Active Learning Methodology in Sustainable Development Curricula. Sustainability 2019, 11, 4577. [CrossRef]

43. Ballantyne, R.; John, F.; Jan, P. School environmental education programme impacts upon student and family learning: A case study analysis. Environ. Educ. Res. 2001, 7, 23-37. [CrossRef]

44. Grodziéska-Jurczak, M.; Anna, S.A.; Katarzyna, N.K.; Bryda, G. Perception of Environmental Problems Among Pre-school Children in Poland. Int. Res. Geogr. Environ. Educ. 2006, 15, 62-76. [CrossRef]

45. Seidman, I.E. Interviewing as Qualitative Research. A Guide for Researchers in Education and the Social Science; Teachers College Press: New York, NY, USA, 1998.

46. Siraj-Blatchford, J.; Mogharreban, C.; Park, E. International Research on Education for Sustainable Development in Early Childhood; Springer: Cham, Switzerland, 2016; p. 14. [CrossRef]

47. Hopkins, C. Scope and Impact of Global Actions under UNDESD. J. Educ. Sustain. Dev. 2014, 8, 113-119. [CrossRef]

48. Ärlemalm-Hagsér, E.; Sue, E. Special Issue: Contemporary Research on Early Childhood Education for Sustainability. Int. J. Early Child. 2017, 49, 267-272. [CrossRef]

49. Aznar, M.; Pilar, M.; Martinez-Agut, P.; Belen, P.; Albert, P.; Ull, M.A. Introducing sustainability into university curricula: An indicator and baseline survey of the views of university teachers at the University of Valencia. Environ. Educ. Res. 2011, 145-166. [CrossRef]

50. Martínez, A.; Pilar, M.; Ull, M.A.; Pilar, A.M. Education for sustainable development in early childhood education in Spain. Evolution, trends and proposals. Eur. Early. Child. Educ. Res. J. 2014, 22, 213-228. [CrossRef] 